\title{
PENGARUH PENAMBAHAN ANGKAK DAN KOMBINASI FILLER TEPUNG TERIGU DAN TEPUNG KETELA RAMBAT TERHADAP KUALITAS SOSIS SAPI
}

\section{EFFECT OF ANKA RICE ADDITION AND FILLER COMBINATION OF WHEAT FLOUR AND SWEET POTATO FLOUR ON BEEF SAUSAGE QUALITY}

\author{
Dyah Wahyuni $^{1 *}$, Setiyono ${ }^{2}$, dan Supadmo ${ }^{2}$ \\ ${ }^{1}$ Fakultas Pertanian, Universitas Sriwijaya, Jl. Raya Palembang-Prabumulih Km. 32, Indralaya, Ogan Ilir, Sumatera \\ Selatan \\ ${ }^{2}$ Fakultas Peternakan, Universitas Gadjah Mada, Jl. Fauna No. 3, Bulaksumur, Yogyakarta, 55281
}

\section{INTISARI}

Penelitian ini bertujuan untuk mengetahui pengaruh angkak sebagai pewarna alami dengan kombinasi filler terhadap kualitas kimia, fisik, mikrostruktur dan sensoris sosis sapi. Angkak yang digunakan dalam bentuk bubuk dengan level $0 ; 0,1 ; 0,2$ dan $0,3 \%(\mathrm{~b} / \mathrm{b})$. Filler yang digunakan adalah tepung terigu dan tepung ketela rambat dengan kombinasi 20:0, 15:5, 10:10, 5:15 dan 0:20\%. Setiap perlakuan diulang sebanyak 3 kali. Variabel yang diamati adalah kualitas kimia (kadar air, protein, dan lemak), fisik ( $\mathrm{pH}$, daya ikat air, dan keempukan), mikrostruktur, dan sensoris (warna, rasa, tekstur, aroma, dan daya terima). Data kualitas kimia dan fisik sosis dianalisis dengan analisis variansi pola faktorial (4 level angkak x 5 kombinasi filler) dilanjutkan dengan Duncan's New Multiple Range Test (DMRT). Mikrostruktur sosis dianalisis secara deskriptif. Pengujian sensoris dilakukan oleh panelis. Kualitas sensoris dianalisis dengan uji Hedonik Kruskal Wallis, dilanjutkan uji Quantitative descriptive analysis (QDA) dalam model jaring labalaba (spider web). Hasil penelitian menunjukkan bahwa penambahan angkak sebanyak 0,3\% menunjukkan hasil yang terbaik berdasarkan kualitas sensoris $(\mathrm{P} \leq 0,05)$, namun tidak meningkatkan kualitas fisik, kimia, dan mikrostrukturnya. Kombinasi filler tepung terigu dan tepung ketela rambat sebanyak 10:10 tidak mengubah kualitas fisik, mikrostruktur, sensoris, dan kimia secara umum karena hanya kadar protein saja yang berubah secara signifikan $(\mathrm{P} \leq 0,05)$. Penambahan tepung ketela rambat secara signifikan menurunkan kadar protein sosis. Tidak terdapat interaksi antara penambahan angkak dengan kombinasi filler tepung terigu dan tepung ketela rambat.

(Kata kunci: Sosis sapi, Angkak, Filler, Kimia, Fisik, Mikrostruktur, Sensoris)

\section{ABSTRACT}

The experiment was conducted to study the effects of anka rice as a natural coloring and filler combination of wheat flour and sweet potato flour on physical and chemical properties, microstructure and sensory acceptability of beef sausage. Anka rice in powder form was used at level of 0, 0.1, 0.2 and $0.3 \% \mathrm{w} / \mathrm{w}$. The combination of wheat flour and sweet potato flour were 20:0, 15:5, 10:10, 5:15 and 0:20\%. Each treatment was consisted of three replications. The observed variables were chemical quality (moisture, protein and fat content), physical quality (pH, water-holding capacity and tenderness), microstructure and sensory acceptability (color, taste, texture, flavor, and overall acceptability) of beef sausage. The chemical and physical quality data were statistically analyzed using variance analysis of Completely Randomized Design with factorial pattern (4 anka rice level $x$ filler combinations), followed by Duncan's New Multiple Range Test. Sausages microstructure were analyzed descriptively. Sensory acceptability were evaluated by panelists. Sensory acceptability were analysed using Kruskal-Wallis Hedonic test, followed by quantitative descriptive analysis (QDA) in a model of spider web. The results indicated that the addition of anka rice amounting of $0.3 \%$ showed the best results based on sensory acceptability $(P \leq 0.05)$, but it did not change the chemical and physical quality, and also microstructure quality. The addition of filler combination in a ratio of 10:10 did not significantly affect the physical properties, microstructure quality, sensory acceptability and chemical quality in general, only the protein content was significantly $(P \leq 0.05)$ affected. The addition of filler combination of wheat flour and sweet potato flour significantly decreased protein content of sausage. There was no interaction between addition of anka rice and filler combination of wheat and sweet potatoe flour.

(Key words: Beef sausage, Anka rice, Filler, Chemical, Physical, Microstructure, Sensory)

\footnotetext{
* Korespondensi (corresponding author):

Telp. +6281321389825

E-mail: cute_dy@yahoo.com
} 


\section{Pendahuluan}

Daging merupakan salah satu produk utama ternak yang digemari oleh masyarakat disamping telur dan susu. Daging segar mudah rusak karena adanya kontaminasi bakteri sehingga dibutuhkan pengolahan untuk mengawetkan daging tersebut. Pengolahan atau pengawetan daging tidak hanya bertujuan untuk memperpanjang masa simpannya, namun juga untuk mempertahankan nilai gizi serta memberi peluang bagi penganekaragaman jenis olahan daging. Penganekaragaman produk olahan daging ini menghasilkan berbagai produk yang lebih menarik minat konsumen sehingga konsumsi masyarakat akan produk daging meningkat. Hasil produk olahan daging tersebut diantaranya adalah bakso, kornet, dendeng, dan sosis (Sutaryo dan Mulyani, 2004).

Sosis merupakan salah satu produk olahan daging yang sangat digemari masyarakat di Indonesia sejak tahun 1980-an (Effendi, 2009). Mutu produk makanan terutama sosis sangat dipengaruhi oleh beberapa faktor antara lain rasa, warna, tekstur, nilai gizi, dan mikrobiologisnya. Warna merupakan faktor pertama penentu mutu sosis secara visual yang memegang peranan penting terhadap penerimaan konsumen, hal ini disebabkan oleh warna merupakan salah satu karakteristik sensoris yang paling mudah terdeteksi oleh konsumen dibandingkan dengan karakteristik sensoris lainnya seperti aroma dan tekstur. Sosis yang bernilai gizi baik, enak, dan teksturnya sangat baik tidak akan diterima oleh konsumen apabila memiliki warna yang menyimpang dari seharusnya (Sutaryo dan Mulyani, 2004).

Penelitian yang dilakukan Husni et al. (2007), menunjukkan bahwa sosis yang beredar di pasaran mengandung berbagai zat tambahan yang berfungsi sebagai pengawet dan pewarna. Eritrosin dan merah allura dengan kadar maksimal masingmasing sebesar $300 \mathrm{mg} / \mathrm{kg}$ merupakan pewarna makanan yang diizinkan penggunaannya, namun beresiko bagi kesehatan apabila dikonsumsi dalam jangka waktu yang lama (Effendi, 2009). Nitrit yang terkandung di dalam sosis apabila dikonsumsi dapat membentuk nitrosamin yang bersifat toksik dan karsinogenik sehingga berbahaya bagi kesehatan. Pemanfaatan bahan-bahan alami merupakan alternatif pengganti pewarna buatan maupun nitrit yang banyak ditambahkan untuk memperkuat warna merah sosis. Angkak merupakan salah satu contoh bahan alami yang bisa dimanfaatkan sebagai pewarna sosis (Timotius, 2004).

Angkak merupakan produk yang terbuat dari beras yang difermentasi menggunakan kapang
Monascus sp. dan menghasilkan beras dengan warna merah yang merupakan warna pigmen dari kapang tersebut. Negara-negara Taiwan, Jepang, Korea, dan Hongkong memproduksi angkak untuk keperluan sebagai pewarna alami makanan (Pattanagul et al., 2008). Menurut Tisnadjaya cit. Indrawati et al. (2010), angkak berfungsi sebagai pewarna, pembangkit rasa dan pengawet pada makanan karena mengandung oligopeptida dan senyawa monascidin A. Angkak sangat aman digunakan karena tidak mengganggu kesehatan, mudah diproduksi, harga relatif murah dan terjangkau (Fabre et al., 2003). Pewarna ini paling cocok diaplikasikan pada industri sosis.

Sosis dibuat dengan menambahkan filler atau bahan pengisi, dengan tujuan untuk meningkatkan stabilitas emulsi, meningkatkan karakteristik produk, meningkatkan citarasa, dan mengurangi biaya formulasi (Kramlich, 1971). Tepung terigu merupakan salah satu bahan pengisi yang biasa ditambahkan dalam pembuatan sosis (Daulay et al., 2008). Keistimewaan tepung terigu terletak pada kemampuan protein membentuk gluten. Gluten inilah yang mempengaruhi elastisitas produk sosis (Sibuea, 2001), dan elastisitas merupakan parameter penting pada mutu produk sosis (Talib, 2009).

Tepung terigu tidak hanya popular sebagai bahan pembuatan sosis, hampir semua produk makanan menggunakan tepung terigu sebagai bahan bakunya. Permintaan akan tepung terigu yang terus meningkat diakibatkan oleh semakin beragamnya produk makanan berbasis terigu terutama di perkotaan, hal ini menyebabkan naiknya harga tepung terigu (Saragih et al., 2008). Salah satu solusi untuk mengatasi masalah tersebut adalah dengan memanfaatkan tepung dari komoditas tanaman pangan lokal dalam memproduksi makanan berbasis terigu. Salah satu komoditas lokal yang mudah diperoleh dan memiliki harga yang terjangkau adalah ketela rambat (Suarni, 2004).

Ketela rambat atau ubi jalar (Ipomoea batatas) adalah salah satu komoditas tanaman pangan yang dapat tumbuh dan berkembang di seluruh Indonesia (Ambarsari et al., 2009). Pengolahan ketela rambat menjadi tepung merupakan alternatif pilihan utama karena selain lebih awet, praktis untuk disimpan dan mudah untuk digunakan dalam pengolahan selanjutnya. Kandungan serat kasar pada tepung ketela rambat lebih tinggi dibanding tepung terigu yaitu 4,44 dan $1,92 \%$. Tingginya kandungan serat kasar inilah yang menyebabkan struktur tepung ketela rambat menjadi lebih kering dan agak kasar, sehingga dapat digunakan sebagai bahan campuran dengan tepung terigu (Ali dan Ayu, 2009). 
Penambahan angkak dan kombinasi filler tepung terigu dan tepung ketela rambat diharapkan dapat meningkatkan kualitas sosis sapi. Berdasarkan uraian tersebut, perlu dilakukan penelitian untuk mengetahui pengaruh angkak dan kombinasi filler tepung terigu dan tepung ketela rambat terhadap sifat-sifat fisik, kimia, mikrostruktur dan sensoris sosis sapi.

\section{Materi dan Metode}

\section{Bahan-bahan penelitian}

Bahan untuk membuat sosis sapi terdiri dari daging sapi bagian round, susu skim, filler yang terdiri dari tepung terigu, tepung ketela rambat putih, dan kombinasi keduanya, angkak yang digunakan dalam bentuk bubuk yang diperoleh dari pasar tradisional: bawang putih, garam, gula pasir, merica, dan es batu. Selongsong sosis yang digunakan berupa selongsong plastik.

\section{Alat-alat penelitian}

Alat-alat yang digunakan dalam pembuatan sosis adalah pisau dapur, panci, chopper, stuffer, sendok, kompor gas, dan timbangan digital. Alat yang digunakan pada uji kualitas fisik adalah timbangan digital, $\mathrm{pH}$ meter, gelas beaker, pengaduk, dan kertas tisu. Uji keempukan dilakukan dengan menggunakan alat pres bahan makanan yaitu Universal Testing Machine. Pengujian kualitas kimia dilakukan dengan menggunakan food scan merek Foss. Alat yang digunakan pada uji kualitas sensoris adalah kuesioner.

\section{Pembuatan sosis}

Daging sapi yang digunakan dalam penelitian ini adalah bagian gandik yang dipotong kecil-kecil, dibersihkan dari jaringan ikat, kemudian dicincang halus dengan menggunakan chopper. Daging yang telah digiling, kemudian ditambahkan bumbubumbu, susu skim sedikit demi sedikit sampai semua bahan tercampur merata. Adonan dibagi menjadi 5 bagian kemudian masing-masing ditambahkan filler yang terdiri dari tepung terigu dan tepung ketela rambat dengan perbandingan 20:0, $15: 5,10: 10,5: 15$ dan 0:20\%. Adonan tersebut masing-masing dibagi lagi menjadi 4 bagian, kemudian ditambahkan angkak dengan konsentrasi $0,0,1,0,2$ dan $0,3 \%(b / b)$. Penambahan air es dilakukan sedikit demi sedikit sambil diremas-remas dengan tujuan untuk membentuk emulsi adonan. Stuffing adalah proses pengisian dimana adonan dimasukkan ke dalam selongsong plastik yang telah disiapkan dengan menggunakan alat berupa stuffer. Tujuannya adalah untuk memadatkan struktur sosis. Sosis kemudian dikukus selama 30-45 menit pada suhu $85^{\circ} \mathrm{C}$. Sosis kemudian diangkat dan dianginanginkan untuk pengujian selanjutnya.

\section{Uji kualitas kimia}

Pengujian kualitas kimia meliputi kadar air, protein dan lemak dilakukan dengan menggunakan Near Infrared Spectroscopy (NIRS) food scan (Osborne, 2000).

\section{Uji kualitas fisik}

Pengujian kualitas fisik meliputi $\mathrm{pH}$, daya ikat air, dan keempukan. Pengujian $\mathrm{pH}$ dilakukan dengan menggunakan metode Bouton et al. (1971) cit. Soeparno (2009). Uji daya ikat air menggunakan metode Ham (Soeparno, 2009). Uji keempukan dengan menggunakan alat pres bahan makanan Universal Testing Machine (Zwick, 2002).

\section{Pengamatan mikrostruktur sosis}

Tahap-tahap dalam pembuatan preparat sosis terdiri dari persiapan jaringan (sosis), dehidrasi dan penjernihan, infiltrasi parafin (parafinisasi) dan pengeblokan, pemotongan jaringan dan tahap pewarnaan (Kiernan, 1993). Pengamatan preparat sosis menggunakan mikroskop dengan pembesaran 40 kali.

\section{Uji sensoris}

Pengujian sensoris meliputi warna, rasa, tekstur, aroma, dan daya terima sosis (Kartika et al., 1988). Panelis adalah mahasiswa Fakultas Peternakan Universitas Gadjah Mada sebanyak 15 orang.

\section{Analisis data}

Data kualitas fisik dan kimia sosis dianalisis dengan Completely randomized design (CRD) pola faktorial (4 level angkak x 5 kombinasi filler) dilanjutkan dengan Duncan's New Multiple Range Test (DMRT). Mikrostruktur sosis dianalisis secara deskriptif. Kualitas sensoris diuji dengan analisis non-parametrik yaitu uji Hedonik Kruskal Wallis (Steel dan Torrie, 1993), dilanjutkan uji Quantitative Descriptive Analysis (QDA) dalam model jaring laba-laba (spider web) (Zook dan Pearce, 1988).

\section{Hasil dan Pembahasan}

\section{Kualitas kimia sosis}

Hasil uji kualitas kimia (kadar air, protein, dan lemak) sosis dengan penambahan angkak dan kombinasi filler tepung terigu dan tepung ketela rambat disajikan pada Tabel 1 dan 2 .

Kadar air sosis. Penambahan angkak berpengaruh tidak nyata terhadap kadar air sosis sapi, 
Tabel 1. Rerata kualitas kimia sosis sapi dengan penambahan angkak (average of chemical quality of beef sausage with anka rice addition)

\begin{tabular}{lrrrr}
\hline \hline \multirow{2}{*}{ Variabel (variables) } & \multicolumn{3}{c}{ Level angkak (\%) (anka rice level (\%)) } \\
\cline { 2 - 5 } & \multicolumn{1}{c}{0} & \multicolumn{1}{c}{0,1} & \multicolumn{1}{c}{0,2} \\
\hline Kadar air (\%) (moisture content $(\%))^{\mathrm{ns}}$ & $60,82 \pm 0,51$ & $61,15 \pm 0,47$ & $60,81 \pm 0,55$ & $60,74 \pm 0,47$ \\
Kadar protein (\%) (protein content $(\%))^{\mathrm{ns}}$ & $20,31 \pm 0,55$ & $20,28 \pm 0,20$ & $19,92 \pm 0,37$ & $19,86 \pm 0,39$ \\
Kadar lemak $(\%)(\text { fat content }(\%))^{\mathrm{ns}}$ & $4,48 \pm 0,50$ & $4,20 \pm 0,19$ & $3,97 \pm 0,17$ & $3,88 \pm 0,21$ \\
\hline
\end{tabular}

ns Non signifikan.

Tabel 2. Rerata kualitas kimia sosis sapi dengan kombinasi filler tepung terigu dan tepung ketela rambat (average of chemical quality of beef sausage with filler combination of wheat flour and sweet potatoe flour)

\begin{tabular}{|c|c|c|c|c|c|}
\hline \multirow[t]{2}{*}{ Variabel (variables) } & \multicolumn{5}{|c|}{$\begin{array}{l}\text { Kombinasi filler tepung terigu : tepung ketela rambat }(\%) \\
\text { (filler combination of wheat flour and sweet potatoe flour }(\%) \text { ) }\end{array}$} \\
\hline & $20: 00$ & $15: 05$ & $10: 10$ & $5: 15$ & $0: 20$ \\
\hline Kadar air (\%) (moisture content $(\%))^{\mathrm{ns}}$ & $61,18 \pm 0,47$ & $61,18 \pm 0,29$ & $60,61 \pm 0,30$ & $61,03 \pm 0,55$ & $60,4 \pm 0,38$ \\
\hline Kadar protein $(\%)$ (protein content $(\%))$ & $20,55 \pm 0,40^{\mathrm{c}}$ & $20,35 \pm 0,20^{\text {bc }}$ & $20,00 \pm 0,20^{\mathrm{abc}}$ & $19,70 \pm 0,46^{\mathrm{a}}$ & $19,87 \pm 0,13^{\mathrm{ab}}$ \\
\hline Kadar lemak $(\%)(\text { fat content }(\%))^{\text {ns }}$ & $4,42 \pm 0,58$ & $4,23 \pm 0,27$ & $4,12 \pm 0,25$ & $4,02 \pm 0,34$ & $3,88 \pm 0,14$ \\
\hline
\end{tabular}

demikian pula dengan kombinasi filler tepung terigu dan tepung ketela rambat berpengaruh tidak nyata, serta tidak terdapat interaksi pengaruh antara level penambahan angkak dan kombinasi filler tepung terigu dan tepung ketela rambat. Penambahan angkak hingga $0,3 \%$ dan tepung ketela rambat putih hingga $20 \%$ tidak mempengaruhi kadar air sosis sapi. Kadar air pada masing-masing perlakuan jika dibandingkan dengan kontrol menunjukkan kadar air yang relatif sama.

Penambahan angkak berpengaruh tidak nyata terhadap kadar air sosis. Kondisi ini diduga karena kandungan air dalam angkak yang relatif rendah yaitu 9,90\% (Kumari et al., 2009), sehingga tidak berkontribusi dalam meningkatkan kadar air sosis. Menurut hasil penelitian Liu et al. (2010), penambahan angkak hingga level 1,5\% menunjukkan hasil yang tidak signifikan terhadap kadar air.

Penambahan kombinasi filler tepung terigu dan tepung ketela rambat juga berpengaruh tidak nyata terhadap kadar air sosis, hal ini diduga karena kadar air tepung terigu dan tepung ketela rambat relatif rendah sehingga tidak mempengaruhi kadar air sosis. Kadar air tepung terigu dan tepung ketela rambat adalah $12 \%$ dan $10,99 \%$. Menurut pendapat Ali dan Ayu (2009), substitusi tepung terigu dan tepung ketela rambat berpengaruh tidak nyata terhadap kadar air produk makanan.

Kadar air mempengaruhi daya ikat air sosis. Hasil statistik daya ikat air tidak berbeda nyata antar perlakuan, hal ini sesuai dengan kadar air sosis yang juga berbeda tidak nyata. Kadar air sosis menurut Standar Nasional Indonesia (1995) maksimal 67,0\% maka kadar air sosis hasil penelitian masih memenuhi standar SNI.

Kadar protein sosis. Penambahan angkak dalam sosis sapi hingga level $0,3 \%$ berpengaruh tidak nyata terhadap kadar protein sosis sapi. Kadar protein pada masing-masing perlakuan dibanding kontrol relatif sama, hal ini disebabkan oleh kandungan protein angkak relatif rendah yaitu $11,60 \%$ sehingga tidak mempengaruhi kadar protein makanan yang ditambah (Kumari et al., 2009). Menurut hasil penelitian Liu et al. (2010), penambahan angkak hingga level $1,5 \%$ menunjukkan hasil yang tidak signifikan terhadap kadar protein sosis Cina.

Kombinasi filler tepung terigu dan tepung ketela rambat berpengaruh nyata $(\mathrm{P}<0,05)$ terhadap kadar protein sosis sapi, namun tidak terdapat interaksi antara penambahan level angkak dan kombinasi filler tepung terigu dan tepung ketela rambat.

Kadar protein sosis menurun sesuai dengan berkurangnya konsentrasi tepung terigu dan meningkatnya konsentrasi tepung ketela rambat, hal ini disebabkan kadar protein tepung terigu lebih tinggi dari tepung ketela rambat yaitu 8,90\% (Suarni, 2001 cit. Suarni, 2004) dan 4,46\% (Vera, 2006 cit. Ambarsari et al., 2009), sehingga kadar protein sosis menurun sesuai dengan penurunan jumlah tepung terigu.

Standar Nasional Indonesia (1995) telah menetapkan bahwa kadar protein sosis minimal adalah $13 \%$. Kadar protein sosis hasil penelitian ini berkisar antara $19,70-20,55 \%$ sehingga kadar protein sosis masih memenuhi standar SNI. 
Kadar lemak sosis. Penambahan angkak dalam sosis sapi hingga level $0,3 \%$ berpengaruh tidak nyata terhadap kadar lemak sosis sapi. Kadar lemak pada masing-masing perlakuan dibanding kontrol relatif sama. Perlakuan kombinasi filler tepung terigu dan tepung ketela rambat berpengaruh tidak nyata terhadap kadar lemak sosis sapi, dan tidak terdapat interaksi antara penambahan angkak dan kombinasi filler tepung terigu dan tepung ketela rambat.

Hasil penelitian ini menunjukkan bahwa penambahan level angkak hingga $0,3 \%$ tidak mempengaruhi kadar lemak sosis sapi. Menurut Cheng dan Ockerman (1998) penambahan angkak hingga level $150 \mathrm{ppm}$ berpengaruh tidak nyata terhadap kadar lemak daging sapi panggang, begitu juga penelitian yang dilakukan Liu et al. (2010) menunjukkan bahwa penambahan angkak hingga level $1,5 \%$ berpengaruh tidak nyata terhadap kadar lemak sosis Cina.

Kadar lemak sosis pada perlakuan level angkak cenderung menurun namun masih dalam kisaran yang relatif sama, demikian juga dengan kadar lemak sosis pada perlakuan kombinasi filler tepung terigu dan tepung ketela rambat. Kadar lemak yang relatif sama ini dikarenakan rendahnya kadar lemak dari angkak, tepung terigu dan tepung ketela rambat yaitu $1,58 \%$ (Kumari et al., 2009), 1,30\% (Suarni, 2001 cit. Suarni, 2004) dan 1,02\% (Vera, 2006 cit. Ambarsari et al., 2009), sehingga tidak berpengaruh terhadap peningkatan kadar lemak produk makanan.

Kadar lemak hasil penelitian ini berkisar antara 3,88-4,48\%, sementara kadar lemak menurut Standar Nasional Indonesia (1995) adalah maksimal
$25 \%$, sehingga kadar lemak hasil penelitian ini masih memenuhi standar.

\section{Kualitas fisik sosis}

Hasil uji kualitas fisik (uji pH, daya ikat air, dan keempukan) sosis dengan penambahan angkak dan kombinasi filler tepung terigu dan tepung ketela rambat disajikan pada Tabel 3 dan 4 .

Nilai pH sosis. Penambahan angkak berpengaruh tidak nyata terhadap nilai $\mathrm{pH}$ sosis sapi. Penambahan kombinasi filler juga berpengaruh tidak nyata terhadap nilai $\mathrm{pH}$ sosis sapi, serta tidak terdapat interaksi antara penambahan angkak dan kombinasi filler tepung terigu dan tepung ketela rambat. Hasil ini menunjukkan bahwa nilai $\mathrm{pH}$ sosis sapi perlakuan relatif sama dengan nilai $\mathrm{pH}$ sosis sapi kontrol.

Nilai $\mathrm{pH}$ angkak pada saat pengukuran adalah 5,2. Nilai $\mathrm{pH}$ sosis sapi yang berbeda tidak nyata diduga karena jumlah angkak yang ditambahkan pada perlakuan sangat sedikit. Liu et al. (2010) dalam penelitiannya juga melaporkan bahwa $\mathrm{pH}$ sosis Cina dengan penambahan angkak hingga level $1,5 \%$ adalah $\pm 6,3$ dan berpengaruh tidak nyata.

Penambahan kombinasi filler berpengaruh tidak nyata disebabkan oleh nilai $\mathrm{pH}$ tepung terigu dan tepung ketela rambat hampir sama. Nilai $\mathrm{pH}$ tepung terigu dan tepung ketela rambat pada saat pengukuran adalah 6,3 dan 6,5 . Nilai $\mathrm{pH}$ kombinasi filler ini sesuai dengan $\mathrm{pH}$ pada sosis yaitu 6,44 hingga 6,46 , hal ini menunjukkan bahwa $\mathrm{pH}$ sosis relatif sama dengan $\mathrm{pH}$ filler yang digunakan. Endress et al. (1987) dan Bouton et al. (1971) cit. Soeparno (2009) juga menyatakan bahwa apabila bahan dasar dan bahan pendukung produk olahan

Tabel 3. Rerata kualitas fisik sosis sapi dengan penambahan angkak (average of physical quality of beef sausage with anka rice addition)

\begin{tabular}{lcccc}
\hline \hline \multirow{2}{*}{ Variabel (variables) } & \multicolumn{4}{c}{ Level angkak (\%) (anka rice level (\%)) } \\
\cline { 2 - 5 } & 0 & 0,1 & 0,2 & 0,3 \\
\hline $\mathrm{pH}^{\mathrm{ns}}$ & $6,42 \pm 0,01$ & $6,39 \pm 0,03$ & $6,50 \pm 0,02$ & $6,47 \pm 0,02$ \\
$\mathrm{DIA}(\%)(W H C(\%))^{\mathrm{ns}}$ & $38,12 \pm 3,97$ & $42,53 \pm 6,71$ & $46,37 \pm 8,02$ & $43,56 \pm 3,69$ \\
Keempukan $(\mathrm{N})\left(\right.$ tenderness) $^{\mathrm{ns}}$ & $154,18 \pm 19,49$ & $155,25 \pm 12,58$ & $175,43 \pm 28,29$ & $158,29 \pm 16,37$ \\
\hline
\end{tabular}

DIA (WHC): daya ikat air (water holding capacity).

${ }^{n s}$ Non signifikan.

Tabel 4. Rerata kualitas fisik sosis sapi dengan kombinasi filler tepung terigu dan tepung ketela rambat (average of physical quality of beef sausage with anka rice addition)

\begin{tabular}{|c|c|c|c|c|c|}
\hline \multirow{2}{*}{ Variabel (variables) } & \multicolumn{5}{|c|}{$\begin{array}{l}\text { Kombinasi filler tepung terigu : tepung ketela rambat }(\%) \\
\text { (filler combination of wheat flour and sweet potatoe flour }(\%) \text { ) }\end{array}$} \\
\hline & $20: 00$ & $15: 05$ & $10: 10$ & $5: 15$ & $0: 20$ \\
\hline $\mathrm{pH}$ & & & & & \\
\hline DIA & 44 & 4 & 4 & 36 & 66 \\
\hline Keempukan $(\mathrm{N})(\text { tenderness })^{\mathrm{ns}}$ & $155,03 \pm 4,51$ & $146,96 \pm 20,43$ & $150,33 \pm 7,50$ & $166,62 \pm 22,85$ & $185,00 \pm 18,59$ \\
\hline
\end{tabular}

DIA (WHC): daya ikat air (water holding capacity).

${ }^{n s}$ Non signifikan. 
daging memiliki nilai $\mathrm{pH}$ yang sama atau variasinya kecil, maka produk akhirnya juga akan memiliki $\mathrm{pH}$ yang sama.

Daya ikat air (DIA) sosis. Penambahan angkak berpengaruh tidak nyata terhadap nilai DIA sosis sapi. Penambahan kombinasi filler juga berpengaruh tidak nyata terhadap nilai DIA sosis sapi, serta tidak terdapat interaksi antara penambahan level angkak dan kombinasi filler tepung terigu dan tepung ketela rambat. Penambahan angkak hingga taraf $0,3 \%$ tidak mempengaruhi DIA sosis sapi, demikian juga dengan penambahan tepung ketela rambat putih hingga $20 \%$. Nilai DIA pada sosis sapi dengan penambahan angkak masih pada kisaran yang relatif sama dengan nilai DIA sosis sapi kontrol. Cheng dan Ockerman (1998) juga menyatakan bahwa penambahan angkak hingga level $150 \mathrm{ppm}$ tidak berpengaruh nyata terhadap DIA daging sapi panggang.

Daya ikat air dipengaruhi oleh kadar air dalam sosis. Kadar air dipengaruhi oleh kandungan protein tepung yang digunakan sebagai filler. Kadar air yang meningkat dapat disebabkan oleh adanya pengikatan molekul air oleh protein melalui ikatan hidrogen (Purnomo et al., 1998). Kandungan protein angkak, tepung terigu dan tepung ketela rambat relatif kecil yaitu 11,$6 ; 8,9$; dan $4,46 \%$ sehingga kemampuan mengikat air pun rendah.

Keempukan sosis. Penambahan angkak berpengaruh tidak nyata terhadap nilai keempukan sosis sapi. Penambahan kombinasi filler juga berpengaruh tidak nyata terhadap nilai keempukan sosis sapi, serta tidak terdapat interaksi antara penambahan angkak dan kombinasi filler tepung terigu dan tepung ketela rambat. Tidak terdapat interaksi antara penambahan angkak dan kombinasi filler yang mempengaruhi keempukan sosis.

Keempukan sosis sapi cenderung mengalami penurunan sesuai dengan meningkatnya penambahan tepung ketela rambat, hal ini disebabkan oleh kandungan serat kasar tepung ubi jalar lebih tinggi dibandingkan dengan tepung terigu yaitu 4,44\% (Suarni, 2001 cit. Suarni, 2004) dan 1,92\% (Vera, 2006 cit. Ambarsari et al., 2009). Keberadaan tepung ketela rambat di dalam produk makanan menyebabkan produk yang dihasilkan menjadi lebih kompak, sehingga keempukan menurun (Ambarsari et al., 2009).

\section{Mikrostruktur sosis}

Gambar 1 menunjukkan hasil analisis deskriptif karakter mikrostruktur sosis dengan penambahan angkak dan kombinasi filler tepung terigu dan tepung ketela rambat dengan membandingkan mikrograf secara visual dengan perbesaran 10x.
Mikrograf tersebut menunjukkan sosis dengan kombinasi filler tepung terigu dan tepung ketela rambat memiliki gumpalan-gumpalan adonan yang besar dan tidak merata. Semakin banyak penambahan angkak gumpalan adonan semakin tampak tidak beraturan, secara umum gumpalan adonan dan rongga-rongga membentuk adonan yang tidak homogen. Penambahan angkak sebagai pewarna alami tidak terlihat nyata karena pengaruh pewarnaan HE pada preparat.

Sosis yang memiliki mikrostruktur yang paling baik adalah sosis dengan penambahan angkak sebanyak $0,3 \%$ dan kombinasi filler tepung terigu $0 \%$ dan tepung ketela rambat $20 \%$, karena gumpalan adonan dan rongga-rongga tampak homogen dan rapat. Menurut Ariyanti (2006), semakin baik mikrostruktur sosis, maka keempukan semakin menurun.

Sosis dengan kualitas mikrostruktur yang paling rendah adalah sosis dengan penambahan angkak $0,3 \%$ dan kombinasi filler tepung terigu $15 \%$ dan tepung ketela rambat 5\%. Gumpalan adonan dan rongga pada mikrograf relatif tampak tidak homogen dibandingkan dengan mikrograf yang lainnya. Hasil ini diduga karena jumlah tepung terigu yang lebih banyak meningkatkan keempukan, namun menurunkan kualitas mikrostrukturnya (Ariyanti, 2006).

\section{Kualitas sensoris sosis}

Kualitas sensoris merupakan parameter kualitas sosis yang terdiri dari uji warna, rasa, tekstur, aroma, dan daya terima yang diuji secara subyektif oleh panelis. Hasil uji kualitas sensoris sosis dengan penambahan angkak dan kombinasi filler tepung terigu dan tepung ketela rambat disajikan pada Tabel 5 dan 6 .

Hasil pengujian statistik disajikan dalam bentuk diagram jaring laba-laba untuk mengetahui hubungan antara parameter satu dengan parameter yang lain. Diagram uji kualitas sensoris tersebut dapat dilihat pada Gambar 2 dan 3.

Diagram jaring laba-laba pada Gambar 2 dan 3 menunjukkan skor warna, rasa, tekstur, aroma dan daya terima sosis sapi dengan penambahan angkak hingga level $0,3 \%$ berbeda nyata. Penambahan angkak menyebabkan sosis berwarna merah, memiliki rasa lebih enak, tekstur lebih halus, dan aroma yang lebih sedap sehingga daya terima meningkat. Kombinasi filler tepung terigu dan tepung ketela rambat berpengaruh tidak nyata terhadap skor warna, rasa, tekstur, aroma dan daya terima sosis sapi.

Warna sosis. Penambahan angkak dalam sosis sapi hingga level $0,3 \%$ berpengaruh sangat nyata $(\mathrm{P}<0,01)$ terhadap warna sosis sapi. 
Penambahan kombinasi filler tepung terigu dan tepung ketela rambat berpengaruh tidak nyata terhadap warna sosis sapi. Tidak terdapat interaksi antara penambahan angkak dan kombinasi filler yang mempengaruhi warna sosis. Kondisi ini sesuai dengan hasil mikrostruktur sosis yang menunjukkan bahwa angkak, tepung terigu dan tepung ketela rambat memiliki eksistensi sendiri-sendiri, sehingga tidak terdapat interaksi.
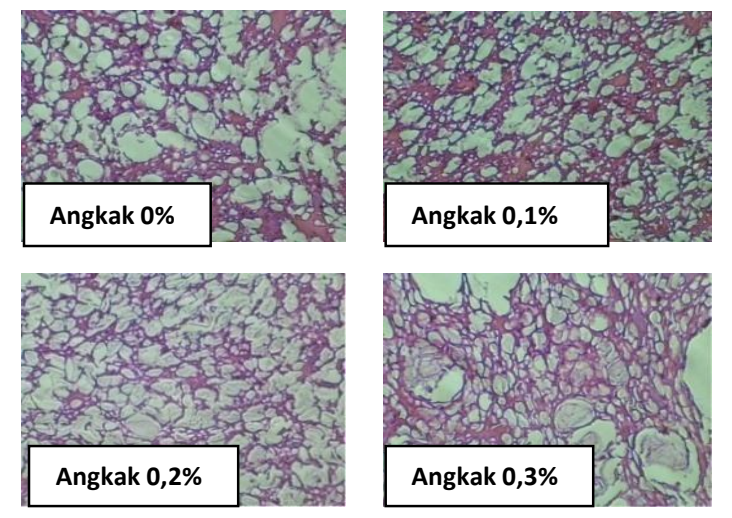

(a)
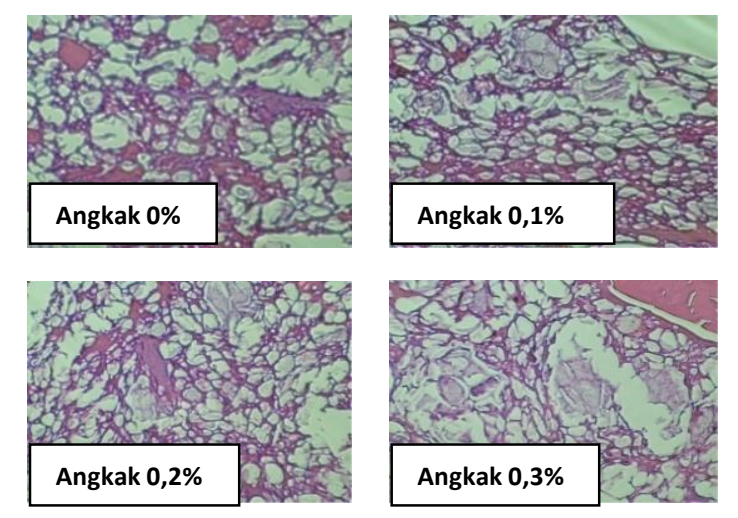

(c)
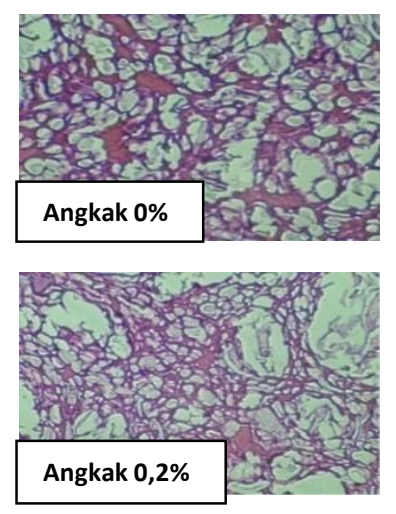

Penambahan angkak berpengaruh sangat nyata $(\mathrm{P}<0,01)$ terhadap warna sosis sapi, hal ini ditandai dengan semakin meningkatnya rerata skor warna sosis sapi sesuai dengan meningkatnya level angkak. Semakin meningkatnya rerata skor warna sosis sapi menunjukkan bahwa warna sosis sapi tersebut semakin merah. Sosis sapi tanpa penambahan angkak sebagai kontrol memiliki rerata skor 1,27 yang berarti berwarna abu-abu agak
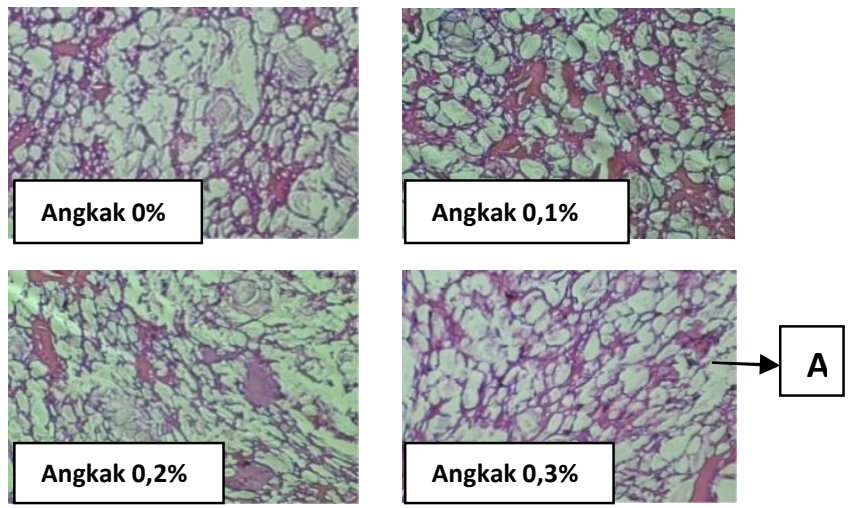

(b)
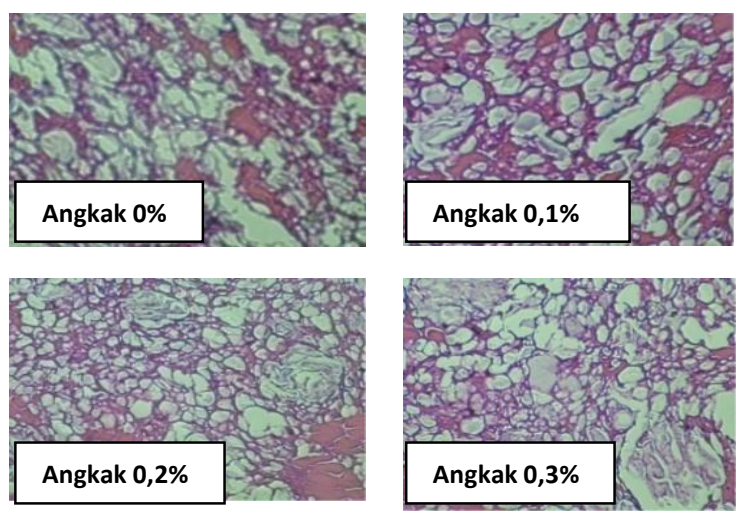

(d)
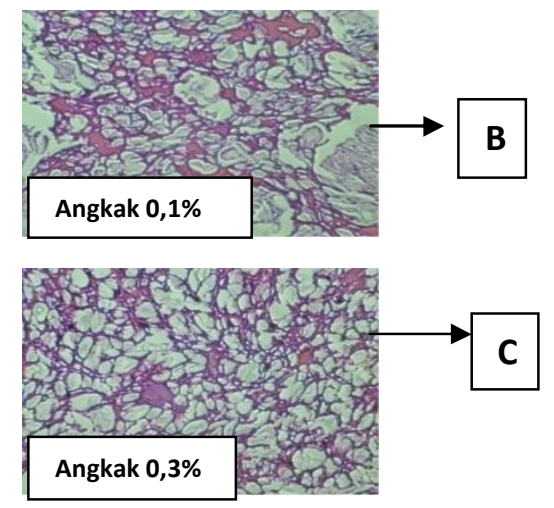

(e)

Gambar 1. Mikrostruktur sosis dengan penambahan angkak dan kombinasi filler tepung terigu dan tepung ketela rambat. Perbandingan tepung terigu dan ketela rambat adalah (a) 20:0\%, (b) 15:5\%, (c) 10:10\%, (d)

5:15\%, dan (e) 0:20\%. A adalah mikrostruktur paling jelek, B adalah gumpalan adonan, dan $\mathrm{C}$ adalah mikrostruktur paling baik. (Sausage microstructure with filler combination of wheat and sweet potatoe flour. Ratio between wheat and sweet potatoe flour were (a) 20:0\%, (b) 15:5\%, (c) 10:10\%, (d) 5:15\% and (e) $0: 20 \%$. A was the worst microstructure, $B$ was lump of mix and $C$ was the best microstructure). 
Tabel 5. Rerata kualitas sensoris sosis sapi dengan penambahan angkak (average of sensory quality of beef sausage with anka rice addition)

\begin{tabular}{lcccc}
\hline \hline \multirow{2}{*}{ Variabel (variables) } & \multicolumn{3}{c}{ Level angkak (\%) (anka rice level (\%)) } \\
\cline { 2 - 5 } & 0 & 0,1 & 0,2 & 0,3 \\
\hline Warna (color) & $1,27 \pm 0,07^{\mathrm{a}}$ & $2,14 \pm 0,23^{\mathrm{b}}$ & $2,80 \pm 0,33^{\mathrm{c}}$ & $3,53 \pm 0,31^{\mathrm{d}}$ \\
Rasa (taste) & $2,99 \pm 0,05^{\mathrm{a}}$ & $3,25 \pm 0,08^{\mathrm{bc}}$ & $3,10 \pm 0,05^{\mathrm{ab}}$ & $3,37 \pm 0,07^{\mathrm{c}}$ \\
Tekstur (texture) & $2,77 \pm 0,14^{\mathrm{a}}$ & $3,02 \pm 0,02^{\mathrm{b}}$ & $3,04 \pm 0,04^{\mathrm{b}}$ & $2,99 \pm 0,06^{\mathrm{b}}$ \\
Aroma & $3,11 \pm 0,06^{\mathrm{a}}$ & $3,22 \pm 0,07^{\mathrm{ab}}$ & $3,12 \pm 0,05^{\mathrm{a}}$ & $3,27 \pm 0,10^{\mathrm{b}}$ \\
Daya terima (acceptability) & $3,18 \pm 0,07^{\mathrm{b}}$ & $3,17 \pm 0,05^{\mathrm{b}}$ & $2,99 \pm 0,10^{\mathrm{a}}$ & $3,22 \pm 0,08^{\mathrm{b}}$ \\
\hline
\end{tabular}

$\overline{a, b, c, d}$ Superskrip berbeda pada baris yang sama menunjukkan perbedaan nyata $(\mathrm{P}<0,05)$ (different superscripts at the same row indicate significant differences $(P<0.05))$.

Tabel 6. Rerata kualitas sensoris sosis sapi dengan kombinasi filler tepung terigu dan tepung ketela rambat (average of sensory quality of beef sausage with filler combination)

\begin{tabular}{|c|c|c|c|c|c|}
\hline \multirow[t]{2}{*}{ Variabel (variables) } & \multicolumn{5}{|c|}{$\begin{array}{l}\text { Kombinasi filler tepung terigu : tepung ketela rambat (\%) } \\
\text { (filler combination of wheat flour and sweet potatoe flour }(\%) \text { ) }\end{array}$} \\
\hline & $20: 00$ & $15: 05$ & $10: 10$ & $5: 15$ & $0: 20$ \\
\hline Warna $(\text { color })^{\mathrm{ns}}$ & $2,46 \pm 0,82$ & $2,46 \pm 0,87$ & $2,45 \pm 0,97$ & $2,55 \pm 1,14$ & $2,26 \pm 1,12$ \\
\hline Rasa $(\text { taste })^{\mathrm{n} \mathrm{s}^{\prime}}$ & $3,12 \pm 0,13$ & $3,21 \pm 0,22$ & $3,16 \pm 0,15$ & $3,24 \pm 0,15$ & $3,17 \pm 0,20$ \\
\hline Tekstur (texture $)^{\mathrm{ns}}$ & $2,93 \pm 0,21$ & $2,95 \pm 0,18$ & $2,92 \pm 0,13$ & $3,00 \pm 0,07$ & $2,98 \pm 0,07$ \\
\hline Aroma $(\text { flavor })^{\text {ns }}$ & $3,16 \pm 0,04$ & $3,21 \pm 0,15$ & $3,15 \pm 0,08$ & $3,20 \pm 0,03$ & $3,20 \pm 0,15$ \\
\hline Daya terima (acceptability) $)^{\mathrm{ns}}$ & $3,14 \pm 0,10$ & $3,13 \pm 0,16$ & $3,08 \pm 0,12$ & $3,16 \pm 0,12$ & $3,20 \pm 0,08$ \\
\hline
\end{tabular}

ns Non signifikan.

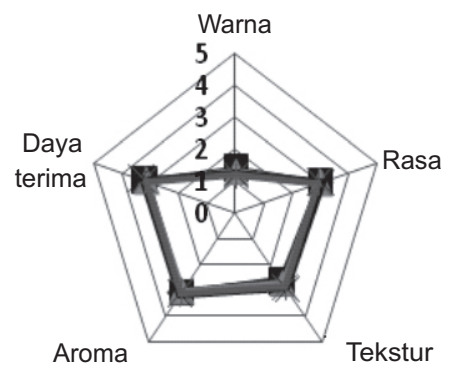

(a)

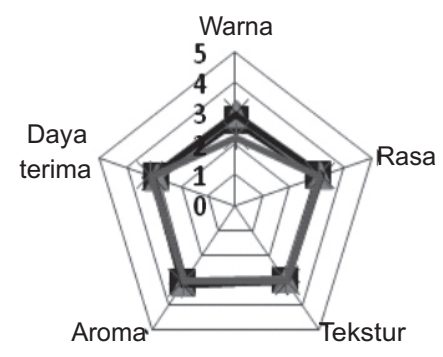

(c)

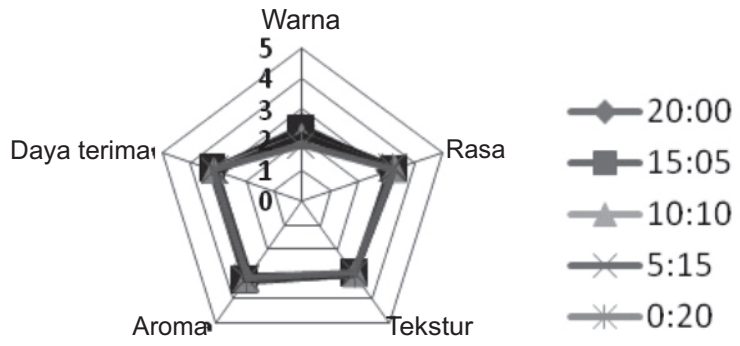

(b)

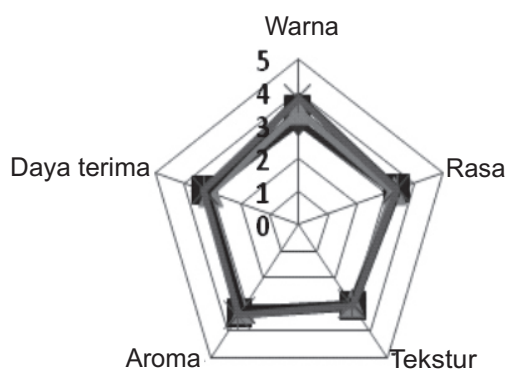

(d)

Gambar 2. Diagram jaring laba-laba sosis sapi dengan penambahan angkak (spider web diagram of beef sausage with anka rice addition) (a) $0 \%$, (b) $0,1 \%$, (c) $0,2 \%$ dan (d) $0,3 \%$.

kecoklatan, dan penambahan level angkak hingga $0,3 \%$ menyebabkan warna sosis menjadi merah cerah sesuai dengan rerata skor 3,53. Liu et al. (2010) juga menyatakan bahwa penambahan angkak dapat meningkatkan warna merah pada sosis. Warna merah pada sosis disebabkan oleh pigmen monascin, ankaflavin, rubropunctatin dan pigmen merah monascorubramine yang dihasilkan oleh M. purpureus (Chen dan Johns, 1993 cit. Liu et al., 2010). 


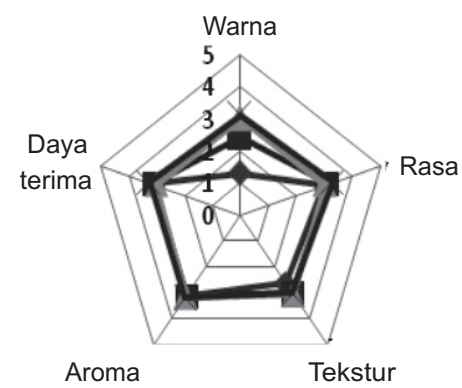

(a)

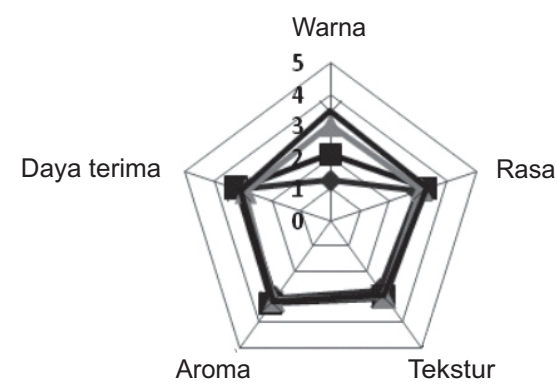

(c)

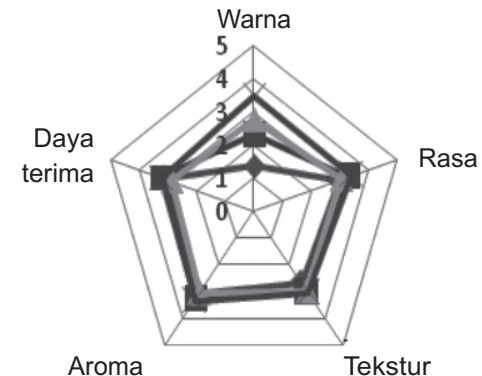

(b)

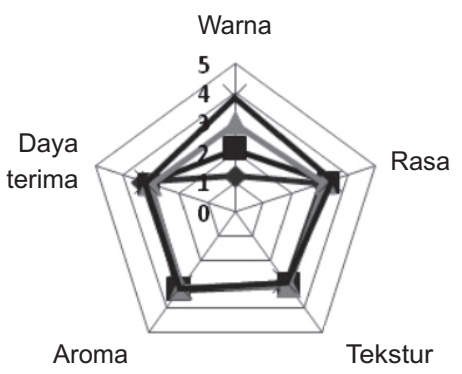

(d)

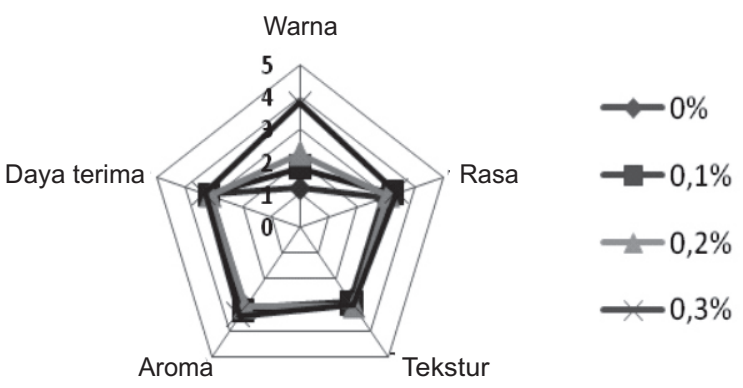

(e)

Gambar 3. Diagram jaring laba-laba sosis sapi dengan kombinasi filler tepung terigu dan tepung ketela rambat (spider web diagram of beef sausage with filler combination of wheat flour and sweet potatoe flour) (a) 20:0, (b) 15:5, (c) 10:10, (d) 15:5 dan (e) 0:20.

Rasa sosis. Penambahan angkak berpengaruh sangat nyata $(\mathrm{P}<0,01)$ terhadap rasa sosis sapi. Skor rasa meningkat seiring meningkatnya level angkak yang ditambahkan di dalam sosis sapi. Skor rasa terendah diperoleh pada sosis tanpa penambahan angkak sebagai kontrol. Penambahan angkak hingga level $0,3 \%$ dapat meningkatkan skor rasa sosis sapi dari agak enak mendekati enak. Hasil penelitian Endogrul dan Azirak (2004); Tisnadjaya cit. Indrawati et al. (2010), menunjukkan bahwa angkak mengandung alfaamylase, oligopeptida dan senyawa monascidin $A$ dalam jumlah yang cukup tinggi sehingga dapat mengubah pati menjadi glukosa, sehingga sosis yang dihasilkan memiliki rasa yang agak manis dan gurih.

Perlakuan kombinasi filler tepung terigu dan tepung ketela rambat berpengaruh tidak nyata terhadap rasa sosis sapi, serta tidak terdapat interaksi antara penambahan level angkak dan kombinasi filler yang mempengaruhi rasa sosis. Hasil penelitian Herawati dan Widowati (2009) menunjukkan bahwa penambahan tepung ketela rambat ke dalam campuran bahan makanan hingga 90\% tidak mempengaruhi rasa produk akhir yang dihasilkan. Rasa sosis berdasarkan penilaian panelis adalah agak enak pada setiap kombinasi, hal ini diduga karena adanya keseragaman dalam pembuatan sosis sapi. Penambahan bumbu-bumbu lebih mempengaruhi rasa sosis daripada filler yang ditambahkan sebagai perlakuan. Penambahan bumbu dalam jumlah yang sama akan menghasilkan rasa sosis yang relatif sama (Purnomo et al., 1998).

Tekstur sosis. Penambahan level angkak berpengaruh sangat nyata $(\mathrm{P}<0,01)$ terhadap tekstur 
sosis sapi. Skor tekstur sosis sapi terendah diperoleh pada sosis tanpa penambahan angkak sebagai kontrol yang menunjukkan bahwa sosis memiliki tekstur yang kasar mendekati agak halus. Penambahan level angkak $0,1 \%$ hingga $0,2 \%$ mampu meningkatkan skor tekstur sosis menjadi agak halus, meskipun pada penambahan 0,3\% mengalami penurunan skor namun masih dalam tekstur agak halus. Kondisi ini diduga karena warna merah yang disebabkan oleh penambahan angkak memperjelas penampilan tekstur sosis sapi, sehingga dapat diketahui tekstur sosis tanpa penambahan angkak dan dengan penambahan angkak secara visual tampak berbeda.

Tekstur daging olahan sangat dipengaruhi oleh macam daging, metode pengolahan, dan bahan-bahan yang ditambahkan (Kramlich, 1971). Bahan yang ditambahkan adalah filler, dan pada penelitian ini digunakan kombinasi filler tepung terigu dan ketela rambat. Perlakuan kombinasi filler tepung terigu dan tepung ketela rambat berpengaruh tidak nyata terhadap tekstur sosis sapi, serta tidak terdapat interaksi antara penambahan level angkak dan kombinasi filler yang mempengaruhi tekstur sosis. Tekstur sosis sapi pada setiap perlakuan kombinasi filler menunjukkan hasil yang sama yaitu sosis tersebut memiliki tekstur yang agak halus, hal ini menunjukkan bahwa penambahan kombinasi filler tepung terigu dan ketela rambat tidak mempengaruhi tekstur sosis sapi. Hasil penelitian Herawati dan Widowati (2009) menunjukkan bahwa penambahan tepung ketela rambat ke dalam campuran bahan makanan tidak mempengaruhi tekstur produk akhir yang dihasilkan.

Aroma sosis. Penambahan angkak berpengaruh nyata $(\mathrm{P}<0,05)$ terhadap aroma sosis, hal ini ditandai dengan semakin meningkatnya rerata skor aroma sosis sesuai dengan meningkatnya level angkak. Skor terendah diperoleh sosis tanpa penambahan angkak sebagai kontrol, meskipun kisaran skor masih sama, namun penambahan angkak dapat meningkatkan aroma sosis dari agak sedap mendekati sedap. Chen (1993) cit. Cheng dan Ockerman (1998) juga menyatakan bahwa penambahan angkak pada produk daging tidak hanya berperan sebagai pewarna, namun juga untuk meningkatkan aroma. Menurut Indrawati et al. (2010), angkak memiliki aroma seperi karamel sehingga dapat meningkatkan aroma suatu produk makanan.

Perlakuan kombinasi filler yang berbeda (tepung terigu dan tepung ketela rambat) berpengaruh tidak nyata terhadap aroma sosis, serta tidak terdapat interaksi antara penambahan level angkak dan kombinasi filler yang mempengaruhi aroma sosis. Aroma sosis pada setiap perlakuan kombinasi filler yang berbeda menunjukkan hasil yang sama yaitu sosis tersebut memiliki aroma yang agak sedap, hal ini menunjukkan bahwa penambahan kombinasi filler yang berbeda tidak mempengaruhi dan merubah aroma sosis. Hasil penelitian Herawati dan Widowati (2009) menunjukkan bahwa penambahan tepung ketela rambat kedalam campuran bahan makanan tidak mempengaruhi aroma produk akhir yang dihasilkan.

Daya terima sosis. Penambahan level angkak berpengaruh sangat nyata $(\mathrm{P}<0,01)$ terhadap daya terima sosis, hal ini ditandai dengan peningkatan rerata skor daya terima sosis hingga level angkak 0,3\%. Baranová et al. (2004) cit. Mal'a et al. (2010) juga berpendapat bahwa penggunaan angkak ke dalam suatu produk makanan tidak hanya dapat meningkatkan kualitas warna saja, namun juga meningkatkan kualitas sensoris produk makanan secara keseluruhan.

Hasil rerata skor daya terima menunjukkan penilaian panelis terhadap tingkat kesukaan sosis yang menurun pada awal penambahan level angkak, namun meningkat (masih dalam kisaran agak suka) pada level angkak 0,3\%. Peningkatan skor daya terima ini diduga karena penggunaan angkak sebagai pewarna makanan masih sangat jarang, bahkan sebagian besar panelis (35 orang dari total 45 orang panelis) tidak mengetahui tentang angkak, sehingga penggunaan angkak dirasakan sebagai pengalaman baru dalam mengkonsumsi sosis sehingga daya terima sosis menjadi meningkat.

Penambahan kombinasi filler tepung terigu dan tepung ketela rambat menunjukkan hasil yang tidak berbeda nyata terhadap daya terima sosis sapi, serta tidak terdapat interaksi antara penambahan angkak dan kombinasi filler. Skor daya terima adalah agak suka, hal ini dipengaruhi oleh sifat-sifat sensoris lainnya yaitu warna, rasa, tekstur, dan aroma yang juga tidak berbeda nyata, sehingga daya terima sosis pun menjadi tidak berbeda nyata.

\section{Kesimpulan dan Saran}

\section{Kesimpulan}

Penambahan angkak sebanyak $0,3 \%$ menunjukkan hasil yang terbaik berdasarkan kualitas sensoris, namun tidak meningkatkan kualitas kimia, fisik, dan mikrostrukturnya. Kombinasi filler tepung terigu dan tepung ketela rambat sebanyak 10:10 tidak berpengaruh pada kualitas fisik, mikrostruktur, sensoris, dan kimia secara umum. Tidak terdapat interaksi antara penambahan angkak dengan kombinasi filler tepung terigu dan tepung ketela rambat.

\section{Saran}

Penambahan angkak yang disarankan dalam pembuatan sosis adalah 0,3\%. Kombinasi filler 
tepung terigu dan tepung ketela rambat yang disarankan dalam pembuatan sosis adalah sebesar 10:10. Perlu dilakukan penelitian lebih lanjut terhadap total mikroba dan daya simpan sosis.

\section{Daftar Pustaka}

Ali, A. dan D.F. Ayu. 2009. Substitusi tepung terigu dengan tepung pati ubi jalar (Ipomoea batatas L.) pada pembuatan mie kering. SAGU. 8 (1): 1-4.

Ambarsari, I., Sarjana, dan C. Abdul. 2009. Rekomendasi dalam penetapan standar mutu tepung ubi jalar. Jurnal Standarisasi 11 (3): 212-219.

Ariyanti, R. 2006. Pengaruh substitusi tahu dan jenis binder terhadap kualitas fisik dan mikrostruktur sosis sapi. Skripsi. Fakultas Peternakan. Universitas Gadjah Mada. Yogyakarta.

Cheng, J-H. and H.W. Ockerman. 1998. Effects of anka rice, nitrite, and phosphate on warmedover flavor and palatability characteristics in roast beef. Meat Science 49 (1): 65-78.

Daulay, A.H., U. Budi, dan D.T. Yudhitama. 2008. Penambahan tepung terigu sebagai bahan pengikat pada kualitas sosis daging ayam. Jurnal Agribisnis Peternakan 4 (3): 76-80.

Effendi, S. 2009. Teknologi Pengolahan dan Pengawetan Pangan. CV. Alfabeta. Bandung.

Endogrul, O. and S. Azirak. 2004. Review of the studies on the red yeast rice (Monascus purpureus). Turkish Electronic Journal of Biotechnology 2: 37-49.

Fabre, C.E., G. Goma and P.J. Blanc. 2003. Production and food applications of the red pigments of Monascus ruber. Journal Food Science 58 (5): 1099-1102.

Herawati, H. dan S. Widowati. 2009. Karakteristik beras mutiara dari ubi jalar (Ipomea batatas). Buletin Teknologi Pascapanen Pertanian 5: $39-44$

Husni, E., A. Samah, dan R. Ariati. 2007. Analisa zat pengawet protein dalam makanan siap saji sosis. Jurnal Sains dan Teknologi Farmasi 12 (2): 108-111.

Indrawati, T., D. Tisnadjaja, dan Ismawatie. 2010. Pengaruh suhu dan cahaya terhadap stabilitas angkak hasil fermentasi Monascus purpureus 3090 pada beras. Jurnal Farmasi Indonesia 5 (2): 85-92.

Kartika, B., P. Hastuti, dan W. Supartono. 1988. Pedoman Uji Inderawi Bahan Pangan. Gadjah Mada University Press. Yogyakarta.
Kiernan, J.A. 1993. Histological and Histochemical Method: Theory and Practice. $3^{\text {rd }}$ ed. Pergamon Press, USA.

Kramlich, W.E. 1971. Sausage products. In: The Science of Meat And Meat Products. $2^{\text {nd }}$ ed. J.F.Price dan B.S. Schweigert, Eds. W.H. Freeman and Co., San Fransisco.

Kumari, H.P. Mohan, K.A. Naidu, S. Vishwanatha, K. Narasimhamurthy and G. Vijayalakshmi. 2009. Safety evaluation of Monascus purpureus red mould rice in albino rats. Food and Chemical Toxicology 47: 1739-1746.

Liu, D.C., S.W. Wu and F.J. Tan. 2010. Effects of addition of anka rice on the qualities of lownitrite chinese sausages. Food Chemistry 118: 245-250.

Mal'a, P., M. Baranová, D. Marcinčáková and J. Nagy. 2010. Organoleptic evaluation of poultry meat products with wheat protein seitan, coloured by microbial natural pigment. Assam University Journal of Science \& Technology. Biological and Environmental Sciences 5 (1): 1-5.

Osborne, B.G. 2000. NIRS. Australia. BRI Australia. Ltd.

Pattanagul, P., R. Pinthong., A. Phianmongkhol and S. Tharatha. 2008. Mevinolin, citrinin and pigments of adlay angkak fermented by Monascus sp. International Journal of Food Microbiology 126: 20-23.

Purnomo, H., D. Rosyidi, dan I. Atina. 1998. Kajian substitusi tepung lupin sebagai binder terhadap kualitas sosis daging sapi. Buletin Teknologi dan Industri Pangan 9 (1): 11-15.

Saragih, B., O. Ferry, dan A. Sanova. 2008. Kajian pemanfaatan tepung bonggol pisang (Musa paradisiaca Linn.) sebagai substitusi tepung terigu dalam pembuatan mie basah. Jurnal Teknologi Pertanian 3 (2): 63-67.

Sibuea, P. 2001. Penggunaan gum xanthan pada substitusi parsial terigu dengan tepung jagung dalam pembuatan roti. Jurnal Teknologi dan Industri Pangan 12 (2): 108-116.

Soeparno. 2009. Ilmu dan Teknologi Daging. Cetakan Kelima. Gadjah Mada University Press, Yogyakarta.

Standar Nasional Indonesia. 1995. Sosis. Jakarta: Badan Standarisasi Nasional. (SNI 01-3820).

Steel, R.G.D. dan J.H. Torrie. 1993. Prinsip dan Prosedur Statistika Suatu Pendekatan Biometrik. Edisi 2. PT. Gramedia Pustaka Utama, Jakarta.

Suarni. 2004. Pemanfaatan tepung sorghum untuk produk olahan. Jurnal Litbang Pertanian 23 (4): 145-151. 
Sutaryo dan S. Mulyani. 2004. SNI Bahan Olahan. Available at http://eprints.undip.ac.id/ 21232/1/838-ki-fp-04.pdf. Accession date: 20 Februari, 2011.

Talib, A. 2009. Pengaruh penambahan emulsifier lemak dalam pembuatan sosis ikan tenggiri (Scomberomuros comerson). Jurnal Ilmiah Agribisnis dan Perikanan. Agrikan UMMU, Ternate 2 (1): 42-50.
Timotious, K.H. 2004. Produksi pigmen angkak oleh Monascus. Jurnal Teknologi dan Industri Pangan 15 (1): 79-86.

Zook, K.L. and J.H. Pearce. 1988. Quantitative Descriptive Analysis. In Applied Sensory Analysis of Foods. Moskowiz, H. (ed.). CRC Press Inc. Boca Raton, Florida.

Zwick. 2002. Universal Testing Machine. Panduan Alat di Laboratorium Rekayasa Pangan, Fakultas Teknologi Pertanian, Universitas Gadjah Mada, Yogyakarta. 